\title{
THE END OF LIBERALIZATION IN COMMUNIST ROMANIA*
}

\author{
CEZAR STANCIU \\ University Valahia
}

\begin{abstract}
A B STRACT. In July I97I, one of the most non-conformist and Western-oriented leaders in the Soviet bloc, made what appeared to many as a radical turn of his domestic policy: liberalization of arts, culture, and social life were drastically limited and the communist party engaged on a course which was strongly inspired by Stalinism. Since then, questions had been raised as to the reasons and the timing of the change. This article explores various hypotheses in light of newly available archival documents in order to assess the role of the external factors in precipitating or determining the change. Soviet pressures are considered as well as the Chinese source of inspiration, as the change had been initiated shortly after Nicolae Ceausescu's visit to China, demonstrating that the change was the product of interfering factors. What appeared at the time to be a sudden and unexpected change had in fact been prepared years before, under various forms. Romania was at the time dealing with growing social expectations due to liberalization measures, just as most other East European societies, but Ceausescu chose to react differently, in the Chinese-style of mass mobilization, aiming to consolidate his party's grip on society and avert risks of Soviet intervention.
\end{abstract}

'Life under a relaxed Communism' was a banner used by Time magazine sometime in the spring of 1966 to describe living conditions in Romania. ${ }^{1}$ Indeed, the 1960 s was a good time for Romanians, as the communist regime, aiming to affirm its autonomy in front of Moscow and pursue its nationalcommunist project, seemed to lean closer and closer to the West. The cultural and ideological restrictions of the Stalinist era had slowly faded away and Romania appeared to be headed for a different version of Communism, one relying on liberalization and openness to the West. Encouraged by Nicolae Ceaussescu's vehement condemnation of the Soviet-led intervention in Czechoslovakia, most Romanians hoped that the regime was indeed reforming. But hopes would not last for long: in 1971, the same Nicolae Ceaussescu who, in 1969, welcomed Richard Nixon to Bucharest - in the first visit of an American

Faculty of Humanities, Department of History, University Valahia, 35 Lt. Stancu Ion, Târgovişte I3ого5, Romania cezar.stanciu@centrulgafencu.ro

* This work was supported by a grant of the Romanian National Authority for Scientific Research.

${ }^{1}$ Time Magazine, 87 (1966). 
president to a communist country-radically changed the course of domestic politics.

Starting from 1962, when Soviet leader Nikita Khrushchev announced his programme of CMEA (Council for Mutual Economic Aid) reformation, Romanian communists had been constantly challenging Moscow's domination of the Soviet bloc. They kept a neutral stance in the Sino-Soviet split and cultivated positive relations with China, they opposed Warsaw Pact reformation, and they tried to find economic support in the West. ${ }^{2}$ Recent studies agree that the source of this dangerous course of policy is to be found in Khrushchev's deStalinization, which threatened the stability of the regime in Romania. ${ }^{3}$ Gheorghe Gheorghiu-Dej, the first party boss in Romania, had been appointed by Stalin to lead the PCR (Romanian Communist Party) and remained loyal to the Stalinist model of development for the rest of his life.

As recent studies emphasized, the change in Romanian-Soviet relations consisted in Gheorghiu-Dej's option for a national way of building socialism, in proclaiming the 'Nation' as master-symbol of regime identity, in many ways similar to Stalin's option for building socialism in one country. 4 Vladimir Tismăneanu used the concept 'National Stalinism' to define this type of regime, stressing the absence of any real form of liberalization, its autarky and reliance on political voluntarism. 5

When Gheorghiu-Dej died in March 1965, Nicolae Ceaussescu maintained the same course of policy. The emergence of Romanian-Soviet divergences and the economic reorientation towards the Western countries had been accompanied domestically by a relaxation of repression, increase in standards of living, political amnesties, and liberalization of culture. Both Gheorghiu-Dej and later Nicolae Ceausescu tried to convey the message that the abuses of the Stalinist era had been imposed by the Soviet Union and were not the responsibility of the PCR. Nicolae Ceausescu reached a climax of popularity in August 1968, when he publicly denounced the intervention against the 'Prague Spring' and claimed that Romania shall defend itself if faced with a similar situation. ${ }^{6}$ Such a stand encouraged nationalistic feelings and, supported by liberalization and Westernization of culture and entertainment, gave birth to much optimism among Romanians, as concerned their future.

\footnotetext{
${ }^{2}$ Sergey Radchenko, Two suns in the heavens: the Sino-Soviet struggle for supremacy, I962-1967 (Washington, DC, 2009), p. 84 .

3 For a recent work on this topic, see Dragos Petrescu, 'Building the nation, instrumentalizing nationalism: revisiting Romanian national communism, 1956-1989', Nationalities Papers, 37 (2009), p. $5^{2} 3$.

4 Bogdan C. Iacob, 'Defining the nation: history, identity, and communism in Romania (1964-1966)', Studia Universitatis 'Babes Bolyai', series Historia, 56 (201 1), p. 3 .

5 Vladimir Tismăneanu, 'What was national Stalinism?', in Dan Stone, ed., The Oxford handbook of postwar European history (Oxford, 2012), pp. 462-79.

6 Reneé de Nevres, Comrades no more: the seeds of change in Eastern Europe (Cambridge, MA, 2003 ), pp. $240-1$.
} 
In July 1971, nevertheless, Nicolae Ceauşescu publicized the famous 'July theses' which called for an increase of political education and party control, and blamed 'bourgeois' influences in society and culture. ${ }^{7}$ His theses soon became an elaborate programme in the course of a Central Committee Plenum that was held in November 1971 and made their effects visible in all sectors of life. It seemed to be a return to presumably extinct Stalinist practices of the 195os, which was both surprising and disappointing for all Romanians: the programme was therefore commonly known as the 'Cultural mini-revolution'. The editorial plans of most publishing houses were suddenly changed, television programmes replaced Western motion pictures with propaganda and artists were once again called upon to serve the purpose of 'socialist construction'.

What was the cause of such a radical turn? Academic literature on the topic encompasses numerous nuances but most seem to be based on a rather peculiar coincidence: Ceaussescu announced his theses only weeks after an extended visit to China and North Korea, in June 1971. Historians noticed the striking similarities between the Asian models of communism, strongly inspired by Stalinism, and the evolutions which followed the infamous 'July theses'. English historian Dennis Deletant argued that Mao Zedong and Kim Ir Sen were a source of inspiration for Ceaussescu, especially in what concerned the cult of personality. ${ }^{8}$ The 'Cultural mini-revolution' was indeed the framework for Ceaussescu's emerging cult of personality in the following years. Also, political scientist Vladimir Tismăneanu defended a similar point of view in his studies on Romanian communism.9

Assessments from Romanian academics seem to be differing somehow; without denying the similarities with the Chinese model, late historian Florin Constantiniu believed that the basic cause for Ceaussescu's change of policy were Soviet pressures. Moscow had obviously been terribly discontented by Romania's foreign policy and especially its cordial relation with China, and Ceaussescu feared - as Constantiniu argued-accusations of 'deviation' which might have justified or precipitated an intervention similar to that in Czechoslovakia. His 'July theses' would have therefore been aimed at calming the Soviets. Paul Niculescu-Mizil, a former member of Ceaussescu's entourage, also denied that China had been a source of inspiration and related the change of policy to the Soviet factor. ${ }^{10}$

7 Nicolae Ceauşescu, Propuneri de măsuri pentru îmbunătătirea activității politico-ideologice, de educare marxist-leninistă a membrilor de partid, a tuturor oamenilor muncii (Bucharest, 1971), pp. $7-16$.

8 Dennis Deletant, Romania under communist rule (Bucharest, 1999), pp. 118-20.

9 Still, V. Tismăneanu also emphasizes that Ceauşescu did have a predisposition for Stalinism. See Vladimir Tismăneanu, Stalinism for all seasons: a political history of Romanian communism (Berkeley, CA, 2003), p. 206.

${ }^{10}$ Both points of view were published in the volume: Ana-Maria Cătănuş, ed., Sfârşitul perioadei liberale a regimului Ceausescu: Minirevoluţia culturală din I97I (Bucharest, 2005), pp. $45^{-61 \text {. }}$ 
The basic aim of this article is to reassess the 'Cultural mini-revolution' from the perspective of foreign factors and influences, drawing on recently declassified documents from the PCR archives in Bucharest. In spite of the pre-existing national-Stalinist orientation of the regime, this article will prove that foreign factors did play a major role in determining both the timing and the content of the 'Cultural mini-revolution'. The analysis will demonstrate the influence of both Chinese and Soviet factors, but will also bring in another explanation with regard to the timing of Ceausescu's change of course, that is, Poland. This last explanation had so far been unexplored by literature. Comparative methods will also contribute to a better understanding of the topic, in the context of post-1968 evolutions in both Romania and the Soviet bloc.

Prior to July 1971, Romanian communism was indeed relaxed and the most conclusive indicator was the arts. Socialist realism had became by then a sinister memory of the past, more and more translations from Western authors were being published in Romania, literature and arts were in contact with worldwide trends. Even talk of past abuses was partially permitted, as Ceauşescu was trying hard to portray himself as a reformer, blaming past abuses not on the party, but on his predecessor Gheorghiu-Dej.

In the field of foreign policy, the PCR was proud to claim that it maintained equal distance between the Soviets and the Chinese, in their long-drawn dispute. Maintaining good relations with China in the context of the Sino-Soviet split was certainly defiant to Moscow, which is why China did react favourably to Romanian rapprochement initiatives. Until 1963, when Romanian-Soviet disputes at CMEA intensified, Romanians had closely followed the Soviet line in reference to China, keeping a reserved attitude in reference to the Great Leap Forward policy and later joining the anti-Chinese criticism. ${ }^{11}$

Before his ascendance to leadership, Nicolae Ceaușescu's most significant Chinese experience was his participation in a Romanian delegation which visited China in spring 1964 , in an attempt to mediate in the Sino-Soviet polemic. Documents reveal that Romanians generally and Ceausescu specifically have never expressed explicit admiration for the Chinese model. Rather, they viewed China in terms of its position in the world communist movement, defending equality among communist parties. ${ }^{12}$ Later, when in power,

\footnotetext{
${ }^{11}$ After a visist to China in 1959, the Romanian party delegation was rather critical of what it had seen there, especially the 'popular communes'. Both acting leader Gheorghiu-Dej and future leader Ceaussescu were sceptical regarding the efficiency of Chinese domestic policies. See the transcript in: Dan Cătănuş, Între Beijing şi Moscova: România şi conflictul sovieto-chinez (Bucharest, 2004), pp. 59-64.

${ }^{12}$ Florian Banu and Liviu Țăranu, Aprilie 1964 'Primăvara de la Bucurestit': cum s-a adoptat 'Declaratia de independență' a României? (Bucharest, 2004), pp. lii-liii.
} 
Ceauşescu did mention several times that, in his view, the Sino-Soviet polemic was nothing more than a power struggle between two super-powers of world communism. References to domestic Chinese politics are very few, although Ceauşescu advocated tolerance in reference to Chinese excesses, blaming them on specific social and political conditions in that country. ${ }^{13}$

The relation became much closer after the Soviet-led invasion of Czechoslovakia, when Nicolae Ceaussescu not only did not participate but moreover dared to condemn it publicly. Nevertheless, the 'special' relation between the Romanians and the Chinese was never reflected in any field of domestic policy, as it was based mainly on the common denunciation of Moscow's leading role in world communism. This is why the visit Ceauşescu paid to Mao in June 1971 was mostly a foreign policy event.

Upon his return, Ceauşescu summoned a meeting of the Executive Committee - the leading body of the PCR - to present his conclusions and share some impressions. In front of the party leadership, Ceauşescu stated:

Another aspect that deserves attention is the ideological activity. In my opinion, they took a revolutionary turn and we can really speak of a cultural revolution. They put aside - maybe too suddenly, but in my view they did the right thing - all these petty bourgeois mentalities and started again from the very beginning. All of their cultural activity (ballet, theatre), was set on revolutionary bases. They said so: we do not want any bourgeois concept to get here. ${ }^{14}$

Ceauşescu was obviously pleased by what he had seen in China. This meeting took place on 25 June 1971 , and on 6 July 1971 the same leading body of the party was presented by Ceaussescu with a set of proposals nominally aimed at improving political and ideological education in the spirit of MarxismLeninism. The Executive Committee adopted the proposals unanimously, as usual.

The proposals demanded the improvement of the Communist party's leading role in all political and educational activities, increasing the role of political and ideological propaganda and education in schools and universities, as well as in the press, mobilizing the workers and especially the youth in political activities, brigades of voluntary labour, etc. Also, he proposed that radio, television, and

${ }^{13}$ He mentioned that in a conversation with Yugoslav president Iosip Broz Tito. See Stenograma discuțiilor avute cu prilejul vizitei în țara noastră a tovarăşului Iosip Broz Tito, preşedintele Republicii Socialiste Federative Iugoslavia, preşedintele Uniunii Comuniştilor din Iugoslavia (Transcript of the discussions held during the visit paid to our country by cmd. Iosip Broz Tito, president of the Socialist Federative Republic of Yugoslavia, president of the Union of Yugoslav Communists), National Archives of Romania (ANR), fund CC al PCR, section External Relations, file no. $155 / 1966$.

${ }^{14}$ Stenograma şedinței Comitetului Executiv al CC al PCR din ziua de 25 iunie 1971 (Transcript of the Executive Committee of the Central Committee of the Romanian Communist party's meeting of 25 June 1971), ANR, fund CC al PCR-section Chancellery, file no. 72/1971, fo. 26. The translation from Romanian was done by Viorel Buta for Cold War International History Project. 
publishing houses increase their contribution to ideological education and propaganda through their editorial content. ${ }^{15}$ The document was immediately published in the press and was followed by numerous meetings with party activists, cadres responsible for propaganda and education, and especially writers and artists. ${ }^{16}$ Ceauşescu engaged in a very severe criticism of their activity and warned all of them that the party demanded men of letters and arts to play an active role in 'building socialism'. He reiterated ideas that most people thought extinct, that culture must have class content and serve revolutionary causes. ${ }^{17}$

Many wondered where the reformism had been displayed until then and feared the worst in regard to the future. A paradox that both Deletant and Tismăneanu noticed was that Ceauşescu's foreign policy continued to remain just as non-conformist as before, as the July theses only affected domestic politics. The difference between foreign and domestic policy was a paradox of Ceaussescu's rule, as both authors noticed. ${ }^{18}$ During a debate organized by a research institute in Bucharest, Niculescu-Mizil, a high-profile member of nomenklatura, stressed that the proposals were formulated by Ceaussescu himself, on his own initiative, and were not the result of leadership consultations. ${ }^{19}$ This seems to confirm that Ceausescu's experience in China and North Korea had indeed been the source of the July theses. But this is only one part of the story.

Apparently, Ceauşescu's commitment to reinforce party control and domination predated his trip to China. Ion Iliescu, at the time chief of the Agitprop section of the Central Committee, was recalling after 1989 that Ceauşescu was already determined to change the course long before he left for Asia, which confirms Niculescu-Mizil's assertion. ${ }^{20}$ In the transcript of the Executive Committee meeting which convened shortly after Ceaussescu's return from Asia, the secretary general refers on certain occasions to discussions which took place before his departure concerning the need to improve ideological activity. He mentioned a meeting of the Central Committee Secretariat on the same topic. ${ }^{21}$

The PCR archives reveal two transcripts of Central Committee Secretariat meetings which discussed the local party cadres' role and involvement in guiding economic activity in certain counties. Confronted with shortcomings in the local cadres' activity, Ceaussescu called for an analysis of party and state organs aimed at improving their work. The situations the party leadership had

\footnotetext{
15 Ceauşescu, Propuneri de măsuri, pp. 7-16.

16 Scânteia, 7 July 1971.

${ }^{17}$ Liviu Maliţa, ed., Ceauşescu, critic literar (Bucharest, 2007), p. 67 et passim.

18 Tismăneanu, Stalinism for all seasons, p. 188; Deletant, Romania under communist rule, pp. $117-18$.

19 Cătănuş, Minirevolutia culturală din I97I, pp. 34-5.

${ }^{20}$ Ion Iliescu, '1971 - Anul schimbărilor ideologice în România, II', Arhivele totalitarismului, 3-4 (2009), p. 243.

${ }^{21}$ Stenograma şedinţei Comitetului Executiv ... (Transcript of the Executive Committee ...), p. 27.
} 
dealt with on that occasion consisted in misuse of local resources, lack of interest from the cadres at both state and party level, absence of control from central organs. Ceaussescu blamed the work style of both party organizations and that of governmental structures which appeared unable to deal with problems effectively in due time. ${ }^{22}$

In this case, it appears that the decision to reinforce party control was not directly determined by the visit to Asia; the Chinese experience could only stimulate certain trends that were already existent. After liberalization policies had gained momentum, the PCR had to deal with various issues deriving from a weaker party control over society, issues such as intense influences from the West in terms of culture and lifestyle, a gradual erosion of the party spirit and demands for liberties, and increased standards of living coming from below. This was a common problem in the Soviet bloc, encouraged by other factors as well. The events of $195^{6}$ helped each communist regime to realize that a social consensus was necessary in order to ensure stability of governing and attention had to be paid to social demands and expectations. The declining East-West tensions contributed to that evolution, as well.

Each regime dealt with pressures from below in a different manner. János Kádár in Hungary, having obtained power in the troubled aftermath of the 1956 revolution, chose to react favourably to social demands by increasing standards of living in what became known as 'goulash-communism'. Hungarian communists tried - with considerable success - to pacify society after the Soviet intervention by offering welfare measures, certain freedoms of private life, and consumer products, accumulating a rather large foreign debt in the process. ${ }^{23}$ This policy was clearly formulated during a Central Committee Plenum held in 1962, when Kádár called for social reconciliation. His strategy was to seek 'passive compliance' from the people, rather than mobilize masses for political or ideological purposes. ${ }^{24}$

The New Economic Mechanism implemented by Hungary starting from 1968 - although debated since 1965 -was a vast reform programme providing for increased decentralization, flexible price system, and limited the attributes of central planning organs. It represented an expression of the regime's efforts to 'gain recognition from the populace' by means of dialogue. ${ }^{25}$ Although the programme ultimately failed, it did ensure increased standards of living in

${ }^{22}$ Stenograma şedinței Secretariatului CC al PCR din ziua de 25 mai 1971 (Transcript of the Central Committee Secretariat's meeting of 25 May 1971), ANR, fund CC al PCR - section Chancellery, file no. $65 / 1971$, pp. $34^{-8}$.

${ }^{23}$ Dorothee Bohle and Bela Greskovits, 'East-Central Europe's quandary', in Francis Fukuyama, Larry Diamong, and Marc F. Plattner, eds., Poverty, inequality and democracy (Baltimore, MD, 2012), p. 95.

${ }^{24}$ Juan J. Linz and Alfred Stepan, Problems of democratic transition and consolidation: southern Europe, South America, and post-communist Europe (Baltimore, MD, 1996), p. 298.

${ }_{5}^{25}$ Janusz Bugajski, Political parties of Eastern Europe: a guide to politics in the post-communist era (Armonk, NY, 2002), p. 341 . 
Hungary, satisfying, at least partially, social expectations. Economic reforms were accompanied by liberalization in culture and the removal of Stalinist officials from key positions.

Similar evolutions occurred in East Germany, as well, where General Secretary Walter Ulbricht initiated a reforms programme in 1963 , known as the New Economic System. The reforms provided a partial decentralization with the aim of improving efficiency. During the mid-196os, the party paid much more attention to social and welfare measures, as was the case with a significant increase in the minimum wage in 1967 . Pensions were also increased and the five-day work week was regulated, as well. ${ }^{26}$ Ulbricht was convinced that only technological and scientific progress can ensure the success of socialism, but his reforms met with increasing resistance from inside the party which ultimately contributed to his removal in 1971. Still, economic reform measures were accompanied, just as in Hungary, by cultural thaw and decrease in repression. ${ }^{27}$

Czechoslovakia, on the other hand, kept delaying such measures until pressures went out of control. Intense debates concerning legality and the abusive Stalinist trials of the early 195 os were not met with a receptive answer from the regime and neither were public expectations for increased freedom. ${ }^{28}$ This led to a 'crisis of the regime' which Alexander Dubček had not been able to control, leading to the unfortunate turn of events on 21 August 1968. ${ }^{29}$ Failure to respond to social pressures led to tragic events in other countries, too. In Poland, Władisław Gomułka’s decision to increase prices for consumer goods at the end of 1970 led to an outbreak of revolts in the Gdańsk region which had to be repressed by military forces.

His successor, Edward Gierek, made concessions in matters of price levels and tried to ensure reasonable standards of living, even at the cost of a mounting foreign debt. Consumption as an instrument of gaining social acceptance was used by communist regimes, especially in the 1970s, as was the case with Gierek in Poland, Hušak in Czechoslovakia, and Kádár in Hungary. ${ }^{\circ}$ East Germany, which had already been enjoying a high standard of living as compared to other communist states, made even more concessions to

${ }^{26}$ Manfred G. Schmidt and Gerhard Albert Ritter, The rise and fall of a socialist welfare state: the German Democratic Republic (I949-1990) and German unification (1989-1994) (Berlin and Heidelberg, 2013), p. $6_{5}$.

${ }^{27}$ Peter Grieder, 'The leadership of the Socialist Unity Party of Germany under Ulbricht', in Patrick Major and Johnathan Osmond, eds., The workers' and peasants'state: communism and society in East Germany under Ulbricht, I945-I97I (Manchester, 2002), pp. 28-9.

${ }_{28}$ Vladimir V. Kusin, The intellectual origins of the Prague Spring: the development of reformist ideas in Czechoslovakia (Cambridge, 2002), p. 35.

29 Oldřich Tůma, 'Reforms in the Communist party: the Prague Spring and apprehension about a Soviet invasion', in Günther Bischof, Stefan Karner, and Peter Ruggenthaler, eds., The Prague Spring and the Warsaw Pact invasion of Czechoslovakia (New York, NY, 2010), pp. 62-3.

$3^{\circ}$ Paulina Bren and Mary Neuburger, 'Introduction', in Paulina Bren and Mary Neuburger, eds., Communism unwrapped: consumption in Cold War Eastern Europe (Oxford, 2012), p. 12. 
consumerism after the oust of veteran Walter Ulbricht from party leadership and his replacement by Erich Honecker. ${ }^{31}$

The regime in Romania chose to pursue a different strategy. In a recent study of Nicolae Ceaussescu's rule, Polish author Adam Burakowski emphasized the economic difficulties that the PCR had been facing starting from 1969-70. $3^{2}$ Ceauşescu was keen on a programme of rapid development and industrialization which was regarded with scepticism by most members of the leadership, especially technocrats. Apparently, even Premier I. Gh. Maurer opposed Ceaussescu's demands for increasing the indicators of the 1971-5 Five-Year Plan. ${ }^{33}$ Ceauşescu's solution was to appeal to mass mobilization.

Writing about Ceaussescu's personality and political beliefs, Mary Ellen Fischer noted that he appeared to be a revolutionary, in the sense that he was convinced, just as Mao or Khrushchev, that masses can be convinced and mobilized for revolutionary goals by means of propaganda. Ceaussescu, writes Fischer, 'had great faith in the possibilities of education and propaganda to move the masses, and he was just as confident that the masses themselves could move mountains if correctly motivated'. 34 In a recent study of Chinese politics, Marc Blecher pointed out that a specific feature of Maoism was its commitment to activating society: 'it demanded not mere obedience, but active, mobilized assent. It wanted believers, not subjects. '35 Ceaussescu's decision to change the course of domestic policy in the summer of 1971 may not have been determined by his visit to China, but there were similarities nonetheless.

In order to understand the meaning of the 'Cultural mini-revolution', several important conclusions can be derived from the transcript of a private conversation between Nicolae Ceaussescu and Santiago Carillo, leader of PCE (Spanish Communist Party), which took place in February 1971. Carillo had often visited Ceaussescu and the two exchanged views and opinions on ideological and political issues. On that occasion, Ceaussescu was telling Carillo about the party's plans to transform its relation with the masses, by increasing the role of workers in managing enterprises. ${ }^{36}$ This did not involve a

${ }^{11}$ Mark Landsman, Dictatorship and demand: the politics of consumerism in East Germany (Cambridge, MA, 2005), p. 214.

$3^{2}$ Adam Burakowski, Dictatura lui Nicolae Ceausescu, I965-1989: Geniul Carpatilor (Iaşi, 2011 ), pp. 159-63.

33 Ana-Maria Cătănuş, 'The 1971 Cultural Revolution: preliminary assessments', Arhivele totalitarismului, 1-2 (2008), pp. 203-4.

34 Mary Ellen Fischer, Nicolae Ceausescu: a study in political leadership (Boulder, CO, and London, 1989), pp. 166-7.

35 Marc Blecher, China against the tides: restructuring through revolution, radicalism and reform (New York, NY, 2010), p. 183 .

$3^{6}$ Stenograma primirii de către tovarăşul Nicolae Ceauşescu, secretar general al Partidului Comunist Român, a tovarăşului Santiago Carillo, secretar general al PC din Spania 26.II.1980 (Transcript of the meeting between cmd. N. Ceausescu, secretary general of the Romanian Communist party, and cmd. S. Carillo, secretary general of the Spanish CP), ANR, fund CC al PCR - section External Relations, file no. 11/1971, pp. 18-19. 
decision-making role in the way Yugoslavia experimented, but it was rather consultative relations that Ceaussescu had in mind. He was complaining to Carillo that party apparatus and the working masses were somehow disconnected, separated by bureaucracy, and his plan was to bring the workers closer to the party. 37

In this context, he often referred to the unavailability of central party and governmental cadres in travelling to the country, for direct contact with workers and industrial enterprises, and told Carillo that he was aware he would meet with resistance in promoting such measures. $3^{8}$ Another reference is of particular interest-and he was going to reiterate it on another occasionnamely that events in Czechoslovakia were not determined by foreign influences, as Brezhnev claimed. Instead, he lectured Carillo, it was the separation between the party leadership and the working class which caused such evolutions. Czechoslovak party leaders had been isolated from the masses for a long time, Ceaussescu stated, and such situations can only lead to erosion of the party spirit. 39

It appears that he was striving to prevent bureaucratization of the party apparatus and, in that sense, he spoke highly of the Chinese, months before his first visit to China as secretary general:

In this respect, I believe that the Chinese Cultural Revolution must be understood from a different perspective. They said that they were struggling against this bureaucratization and degeneracy. They solved it in their own way. But their conclusion was not to isolate themselves from the masses, but on the contrary, to attract the masses. They called on the youth because it appeared that they succeeded much better in drawing the youth to understand a renewal. $4^{\circ}$

Ceaussescu's 'July theses' laid special emphasis on the youth, as well. His proposal contained large references to the ideological education of youngsters. Political and ideological activity in schools and universities had to be intensified, including by changes of curricula. Local party committees were charged with supervising political and ideological activities in educational units of all levels. The Union of Communist Youth, the party's youth organization, was appointed responsible for arranging educative and entertaining activities with political and ideological content while combating cosmopolitanism and even alcohol consumption..$^{1}$ Ceaussescu was basically resurrecting the party's quest for a 'new man', characteristic of the Stalinist agenda.

In China, involvement of youngsters was a specific feature of the Cultural Revolution. In declaring war against the 'old', be it represented by ideas, habits, traditions, or culture, Mao relied on the well-known Red Guards, groups of enthusiasts, mostly of young age, who assaulted people and institutions,

\footnotetext{
37 Ibid. $\quad 3^{8}$ Ibid. $\quad 39$ Ibid., p. $20 . \quad 4^{\circ}$ Ibid., p. 24 .

$4^{1}$ Ceauşescu, Propuneri de măsuri, pp. 12-13.
} 
claiming to be agents of a new beginning. ${ }^{42}$ Relying upon the masses was a distinct characteristic of Maoism. In Mao's views, as Sujian Guo noted recently, the party 'must go to the masses, mobilize the masses, investigate and discover what problems there are, and solve the problems'. 43 A similar style of mass mobilization was discovered by Mary Ellen Fischer in Ceaussescu and it transpires from various other circumstances, like the countless speeches he delivered during his restless visits throughout the country.

It is therefore evident that, confronted with similar social pressures to the other communist states in Europe, the regime in Romania chose to react differently and employ methods that resemble-and were at least partially inspired by - the Chinese model. But what could account for such a different evolution?

In order to explain the particularities of the regime in Romania, one must first understand the origins and sources of its programme of national-communism. Recent literature generally agrees that it was de-Stalinization, initiated by Nikita Khruschev in 1956, which convinced Gheorghe Gheorghiu-Dej, Ceauşescu's predecessor, that too much dependence on Moscow made him vulnerable. 44 In Romania, the leader had not died, as in the Soviet Union, and full responsibility for Stalinist abuses was laid on his shoulders, which is why he tried to reduce his dependence on the Soviet Union and consolidate his regime by domestic means. Dragos Petrescu argues that Gheorghiu-Dej used national identity as a factor of legitimacy and manipulated it for his party's own benefit, starting from 1956 onwards. 45

Domestic consolidation also involved an economic reorientation aimed to reduce Romanian reliance on Soviet technology and raw materials. GheorghiuDej intensified his industrialization programme and established fruitful relations in the West, trying to substitute the Soviet Union as the most important economic partner. Economic factors were, in the end, responsible for his estrangement from Moscow. In 1962, when Nikita Khrushchev was trying to increase intra-CMEA integration, Gheorghiu-Dej perceived it as a threat against his industrialization programme, against his economic independence, for which reasons he strongly opposed the plans. It was in that context that Romania first approached China, trying to affirm its independent stand in world communism and to gain additional political support.

$4^{2}$ Jiang Jiehong, 'Burden or legacy: from the Chinese Cultural Revolution to contemporary art', in Jiang Jiehong, ed., Burden or legacy: from the Chinese Cultural Revolution to contemporary art (Hong Kong, 2007), pp. 7-11.

43 Sujian Guo, Chinese politics and government: power, ideology and organization (London, 2012), p. $102 . \quad 44$ Tismăneanu, Stalinism for all seasons, pp. 142-8.

45 Petrescu, 'Building the nation ...', 'p. $5^{23}$. 
In this process, historian Dennis Deletant noticed a return to traditional Romanian disputes concerning modernization, which, in the modern age, consisted of two main currents, one defending 'imported' (i.e. European) models of development, the other one defending 'indigenous' models. $4^{6}$ Gheorghiu-Dej's regime, argued Deletant, assumed the 'indigenous' option and reformulated it within the framework of Marxism-Leninism. 'It was upon this appeal to a native self-reliance that First Secretary Gheorghe Gheorghiu-Dej based his political and economic policies', Deletant wrote, adding that 'in this particular case development planning provided a means to break free from dependency upon the Soviet Union'.47 A similar approach on development issues was at the core of China's Great Leap Forward in $195^{8}$ and may help explain future Romanian sympathies towards this country.

Following the comparison with China, one also notices that a key role in Mao Zedong's later dissent of the Soviets was played by Khrushchev's deStalinization, as well. Soon after, Mao realized that too much dependence on the Soviet Union was dangerous for his regime especially because it involved the risk of Soviet influence and interference in domestic Chinese policies, therefore threatening his own supremacy. $4^{8}$ Much like Gheorghiu-Dej later, Mao called upon feelings of patriotic pride when he stated, in April 1956: 'we had been slaves far too long and felt inferior to others in every respect'. The Great Leap Forward, Steven Goldstein pointed out, was after all a choice for development based on domestic resources at the expense of foreign aid. 49

After the Romanian-Soviet divergences broke out, Gheorghiu-Dej stated in a Politburo meeting: 'I like this Chinese thesis that everyone should develop on his own resources. ${ }^{\circ} 5^{\circ}$ Romanian and Chinese communists were both rejecting Moscow's domination of world communism and saw autarchy and economic independence as an instrument to safeguard their regimes against foreign interferences. This is not to imply that Romanians were in any way following the Chinese model, but similar experiences and interests determined similar reactions, augmented by intensified contacts in the 1960 .

After Gheorghiu-Dej's death, Nicolae Ceaussescu arrogated to himself the position as defender of national interests. Just like his predecessor, Ceauşescu too had a threat to deal with: the Soviet-led intervention against the 'Prague Spring'. In this particular case, the situation is different because the threat was

$4^{6}$ Dennis Deletant, 'Romania's return to Europe: between politics and culture', in Raymond Detrez and Barbara Segaert, eds., Europe and the historical legacies in the Balkans (Brussels, 2008), p. 91.

47 Ibid.

$4^{8}$ Jiaqi Yan and Gao Gao, Turbulent decade: a history of the Cultural Revolution, trans. D. W.Y. Kwok (Honolulu, HI, 1996), p. 3 .

49 Steven M. Goldstein, 'Nationalism and internationalism: Sino-Soviet relations', in Thomas W. Robinson and David Shambaugh, eds., Chinese foreign policy: theory and practice (Oxford, 1994), p. 241.

$5^{\circ}$ Stenograma şedinței Biroului Politic al CC al PMR din ziua de 22 iunie 1963 (Transcript of the Political Bureau of the Central Committee of PMR's meeting, 22 June 1963), ANR, fund CC al PCR - section Chancellery, file no. 33/1963, p. 59 . 
that of a military intervention, aimed to limit Romania's policy of independence and its fronde against the USSR. A return to rigid ideological practices can be regarded in two different ways: on one hand, as a form of convincing the Soviets that socialism was not in danger in Romania as it had supposedly been in Czechoslovakia and, on the other hand, as a form of strengthening the party's control over society, an active defence measure in case of intervention.

The narrative of events preceding the enunciation of the 'July theses' can help clarify their meaning. In October 1968, a Central Committee Plenum adopted a series of measures aimed at 'strengthening the moral and political unity of the working people'. $5^{1}$ A new political structure, rather hybrid in its nature, was established on that occasion: the Front of Socialist Unity. It was intended as a mass organization, incorporating the PCR, the Union of Communist Youth, the trade unions, and professional unions, including national minorities, under a sole leadership. The Front of Socialist Unity was a supra-structure but it participated in elections on a common list, had a common leadership, and held periodical congresses. President of the National Council of the Front of Socialist Unity was (obviously) Nicolae Ceauşescu. $5^{2}$

In simple words, it was a new mass organization, incorporating the party and mostly all other forms of professional and social representation in Romania, under the leadership of the PCR and Ceaussescu personally. Given the monoorganizational nature of the political regime in Romania, all the units incorporated in the Front were already under party control, so it could not have been a matter of subjecting them to control. Since control already existed, we can reasonably presume that Ceaussescu only wanted to increase it, to consolidate it, as if he perceived it to be weak. The Constitutive Act of the Front is very explicit as to the aims and hierarchical relations among the member organizations:

Mass, popular and professional organizations, reunited in the Front of Socialist Unity, recognize the Romanian Communist Party as their leading force, as the entire activity of the party had proven its boundless devotion to the vital interests of the homeland, to the cause of Marxism-Leninism, and its high capacity to successfully lead our people on the luminous path of socialism and communism.53

Other stipulations of the Constitutive Act referred to the members' commitment to develop further 'socialist construction' and to serve as a vector for attracting all social and political forces in society to the fulfilment of PCR's policies. There was clearly a relation of subordination between the PCR and all

${ }^{1}$ Scânteia, 25 Oct. 1968.

$5^{2}$ Stenograma şedinţei de constituire a Consiliului Naţional al Frontului Unităţii Socialiste, Bucuressti, 19 noiembrie 1968 (Transcript of the constitutive meeting of the National Council of the Front of Socialist Unity, Bucharest, 19 November 1968), ANR, fund CC al PCR - section Organizational, file no. 71/1968, pp. 8-20.

53 Act Constitutiv (Constitutive Act), ANR, fund CC al PCR - section Organizational, file no. 74/1968, p. 2. 
other organizations and references to public debates regarding the party's policies could not change the fact that such debates were only acceptable as long as they unconditionally accepted the PCR's rule and the ideological nature of these policies. Particularly because of such contradictions, debate could not have an open and reciprocal character, but represented merely a simulacrum, aimed to consolidate the party's control over society.

But the party had never actually lost control of society, especially not in the sense it happened in Hungary in $195^{6}$, in which case legitimate questions arise as to the motive of this initiative. Analyzing it, one could not overlook the timing factor: it happened shortly after the Soviet-led intervention in Czechoslovakia, at a moment when Ceaussescu was seriously considering the possibility of being subjected to a similar intervention. In this context, he was obviously trying to improve the party's grip over society in order to resist successfully an intervention, in other words, trying to restore party-people relations which he believed had broken down in Czechoslovakia. Such pre-emptive measures directed against erosions of party spirit also had the potential to convince the Soviets that socialism was not in danger in Romania.

If the regime perceived a real danger of erosion within the party, that perception was certainly amplified by an event which occurred only a month later. On Christmas Eve, a group of students in Bucharest gathered on the streets, apparently singing carols and having a good time. The group progressively increased its number, turning into a real demonstration, as students headed for the city centre, where the PCR Central Committee was located, and their songs were replaced by political slogans. According to foreign and domestic accounts, the students shouted on the streets in favour of more liberties and against Ceauşescu himself. Surprisingly enough, Ceauşescu was not informed of this until the next morning. Central party cadres as well as officers from the political police intervened, trying to disperse the group by non-violent means, which they apparently succeeded in doing, although some arrests were made nonetheless. 54

In his recent book on Ceaussescu's rule, Adam Burakowski claimed that the origins of the infamous 'July theses' are to be found in these events. 55 At the Executive Committee meeting which convened the next morning, Ceausescu launched a very critical attack on the educational system for failing to reach its ideological tasks, a critique that anticipated the content of the 'July theses':

I think it is time for the comrades responsible for this sector to understand that what we have decided within the party, within the Central Committee, must be applied, that it's not only in factories that we ask for the production plan to be completed. There is a plan here as well, and the plan is to produce cadres armed with our

54 Adam Burakowski, 'Un eveniment important aproape necunoscut: demonstraţia studenților din Bucureşti, 24 decembrie 1968', Arhivele totalitarismului, 1-2 (2006), pp. $238-40$.

55 Burakowski, Dictatura lui Nicolae Ceausescu, p. 157. 
ideological conception, not to provide for the decadents and depraved, for everything that is bad in education. $5^{6}$

Erosion of party spirit was certainly what Ceaussescu warned about. But is there a connection between a potential Soviet threat and Ceausescu's call for strengthening party spirit? Only three years before, at a meeting between the party leadership and the writers, Ceausescu condemned 'socialist realism' and declared that Romanian art must be receptive to evolutions abroad and manifest in a multitude of forms.57 There was certainly a demagogical component to this speech, as he had just been elected as secretary general of the PCR and was trying to build a reputation as a reformer. Vladimir Tismăneanu was certainly right in emphasizing Ceauşescu's predisposition towards Stalinist patterns of political behaviour, but the timing does suggest a connection with the perceived Soviet threat.

In defending the primacy of the Soviet threat in Ceaussescu's decision to steer course, Paul Niculescu-Mizil referred to meetings which took place between Ceaussescu and Brezhnev in 1969 and 1970. On both occasions, the Soviet leader blamed Ceaussescu for his policy of defiance towards Moscow and even suggested that the PCR was headed for 'deviation' - a fatal etiquette to any communist. Florin Constantiniu suggested that the Soviets employed military manoeuvres during Ceauşescu's visit to Asia in June 1971, as a form of intimidation, a fact which contributed to Ceauşescu's sudden decision to change his domestic policies. $5^{8}$

Ceaussescu's public denunciation of the Soviet-led intervention in Czechoslovakia had certainly been very inconvenient for Soviet leader Leonid Brezhnev. In the aftermath of the events, Brezhnev and Ceaussescu did exchange some harsh messages while Warsaw Pact troops were manoeuvring near Romania's borders. Ceaussescu, following a confidential meeting with Yugoslav president, Iosip Broz Tito, tried to appease Brezhnev, refraining from other bellicose speeches and reassuring Moscow of Romania's friendship. 59 Brezhnev and Ceaussescu met in May 1969 to discuss the state of relations between the two parties and states. It was the first time after August 1968 when they met for the sole purpose of discussing this.

Archival evidence shows that Brezhnev was indeed terribly upset with the Romanians, as he repeatedly reproached Ceaussescu for his previous confrontational stance. Brezhnev spoke extensively of Romania's 'departure from the common principles', especially in what concerned its relations with China, its opposition to CMEA and Warsaw Treaty Organization reforms and also its intensive relations with the West. Still, Brezhnev did not refer in any way to such

$5^{6}$ Burakowski, 'Un eveniment important aproape necunoscut', p. 246.

57 Alina Pavelescu and Laura Dumitru, eds., PCR şi intelectualii $̂$ in primii ani ai regimului Ceausescu, 1965-1972 (Bucharest, 2007), p. 24.

$5^{8}$ Cătănus, Minirevolutia culturală din 1971 , pp. $5^{6-9}$.

59 Mihai Retegan, I968: din primăvară până în toamnă (Bucharest, 1998), p. 218. 
a 'departure' in domestic politics. The Soviets did not mention anything regarding a potential weakening of the regime in Romania due to liberalization measures, but only timidly insinuated that an anti-Soviet spirit was being tolerated by the PCR. ${ }^{60}$ It is also interesting to notice that none of the 'July theses' mentioned anything about combating an anti-Soviet spirit; needless to say, the 'Cultural mini-revolution' did not involve any change in Romania's relations to China or the West.

Another meeting to which Niculescu-Mizil referred to as proof that Soviet pressures were exerted occurred in May 1970. Brezhnev's scheduled trip to Romania for the signing of the renewed Romanian-Soviet Treaty of Friendship had been repeatedly postponed after Ceaussescu welcomed American president Richard Nixon in Bucharest, in early August 1969. Brezhnev must have been irritated once again, since he cancelled his participation at the PCR's 1oth Congress. After Nixon's visit, Ceaussescu again tried to appease Brezhnev and it was in that context his visit to Moscow occurred, exactly one year later.

At discussions, Brezhnev again complained about Romanian obstructions to reforms in the Soviet bloc, about Nixon's visit to Bucharest in the midst of the Vietnam War, and about ostensive Romanian opposition to most Soviet positions in international relations. He insisted on two issues nonetheless: intervention in Czechoslovakia and Romanian-Chinese relations. ${ }^{61}$ Brezhnev even implied that if Romania wanted to leave the Warsaw Pact, it would be better to say so. As for domestic politics, Brezhnev referred to the anti-Soviet atmosphere that the PCR appeared to be cultivating in relation to the intervention in Czechoslovakia. Moscow was also irritated by other decisions made in Bucharest in the preceding years, such as closing the RomanianRussian Museum in 1963 while opening an American library. ${ }^{62}$

The meeting in May 1970 can provide some explanations for the 'July theses', as Niculescu-Mizil suggested. On several occasions, Brezhnev referred to Romanian's opening to the West, not only in what concerned cultural relations. The Soviet leader expressed his concern over Romania's increasing economic co-operation with the West and rhetorically inquired if Romania was interested in a re-orientation towards the West. He told Ceausescu that the Soviet Union was being very 'patient' about this. ${ }^{63}$ The 'July theses' did contain significant references to the need to limit "bourgeois" influences from the West. Still, Ceausescu did not surrender to such critiques and defended his decisions in the name of sovereignty and independence, but was careful to assure Brezhnev that he would remain a faithful ally of the USSR. Both meetings prove that the

${ }^{60}$ Stenograma şedinţei Comitetului Executiv al CC al PCR din 16 mai 1969 (Transcript of the meeting of the Executive Committee of CC of PCR, 16 May 1969), ANR, fund CC al PCR - section Chancellery, file no. 75/1969, pp. 6-8.

${ }^{61}$ Stenograma şedinţei Comitetului Executiv al CC al PCR din ziua de 20 mai 1970 (Transcript of the meeting of the Executive Committee of CC of PCR, 20 May 1970), ANR, fund CC al PCR - section Chancellery, file no. 59/197o, pp. 6-1 1.

${ }^{62}$ Ibid., pp. 9-10.

63 Ibid., p. 11. 
Soviets did exert pressure over Romania's independent policies, but the focus of attention was its foreign rather than domestic policy.

In this case, limiting Western influences through measures of ideological retrenchment could be interpreted as a demonstration that co-operation with the West was only conducted at state level, on mostly economic issues, and did not represent an option of domestic policy, as previous liberalization measures might have indicated to careless observers. It seems certain though that the 'July theses' were not the product of one single factor, but of a multitude of factors of which none should be neglected. Ceaussescu's need to assure Brezhnev that Romania was not going to be another Czechoslovakia-as far-fetched as the comparison may be-was combined with his own personal conclusions indicating that the PCR's grip on society was eroding.

Between the May 1970 meeting and the publication of the 'July theses', two other events occurred, which are fundamental to understanding both the content and the timing of the change. The first of these events will be discussed separately, but the second was Ceausescu's meeting with the Soviet leadership upon his return from China and the other Asian countries. Brezhnev, after postponing over and over again his planned visit to Romania, refused to meet Ceaussescu when he made a stop-over in the USSR while returning from Asia. A Politburo delegation led by Premier A. Kosygin met him. Kosygin was very critical of Ceausescu's initiative to visit China, although Moscow had been previously informed of this, and accused him of sabotaging the unity of world communism. His visit to China, the Soviets implied, was an implicit acceptance of Chinese criticism of the Soviet Union, which was a very "unfriendly" gesture. ${ }^{6}$

Once again, it is remarkable that Soviet accusations were directed mostly against Ceauşescu's foreign policy. In this case, it seems less likely that the change of course was a direct product of Soviet pressures, but rather an indirect product. Increasing his grip on society could be regarded as a defensive measure, in an autochthonous, self-reliant perspective, aimed at improving his chances of resistance in front of external pressures. Ever since the August 1968 events in Prague, Ceaussescu seemed more and more interested in consolidating party and personal control and manipulated national sentiments to that effect. The process should also be associated with the fervent resurrection of national symbols. Official propaganda described the PCR as the rightful continuator of the centuries-old Romanian struggle for independence which made way for Ceaussescu's growing cult of personality. The 'July theses' would therefore appear as merely one part of a much wider process.

Comparison with China is again helpful to the analysis. The 'Cultural Revolution' was determined, among various other factors, by Mao's need to

\footnotetext{
${ }^{6}$ Stenograma şedinței Comitetului Executiv, 25 iunie 1971 (Transcript of the Executive Committee, 25 June 1971), ANR, fund CC al PCR, section Chancellery, file no. 72/1971, pp. $3^{8-40 .}$
} 
consolidate his control, in the context of a perceived external threat. ${ }_{5} 5_{5}$ This way, it does not look surprising that, confronted with Soviet pressures, Ceaușescu would choose to limit Western influences and increase communist ideological education, instead of further orienting towards the West. Mao, too, when in need to enhance control, chose to play the ideological card, portraying China as the preserver of Marxist-Leninist truth while limiting foreign influences. But there is yet another factor that needs to be considered, at least concerning the timing.

\section{I I}

The events which took place in Czechoslovakia had been understood by Ceaussescu in terms of his own fight against Moscow, a fight carried at party and state level, in which Romania was claiming its right to independence. He defended the Czechoslovaks and condemned the Soviet-led intervention from a principled position, that of non-interference in domestic affairs. There are virtually no documents to prove that he recognized a social risk to party domination or that he drew a lesson from it, although he certainly received detailed information concerning the evolutions in Prague, in the spring of 1968. When he first began taking measures aimed at consolidating control, in the autumn of 1968, he did so perceiving a danger from abroad (i.e. the USSR) rather than from society.

Yet his perception must have changed radically after the student demonstration in Bucharest, in December 1968. That was probably the first social unrest he had to deal with since gaining power. But in December 1970, new events occurring in Poland warned him of the potential dangers of social turbulence, stemming from a weakened party, unable to contain social expectations. He did see Czechoslovakia in terms of inter-party and inter-state relations, but he could not have seen Poland in the same way, since there was no Soviet intervention there.

Pressured by growing financial imbalances, Władisław Gomułka’s regime in Poland made a decision to increase prices, including for consumer goods, in December $1970 .{ }^{66}$ The decision was met with terrible discontent nationwide, but things slipped out of control on 12 December 1970 in Gdańsk. Industrial workers went on strike and marched to the city centre, where political institutions were located, and the movement evolved into a riot, gathering momentum. Gomułka, lacking any political intuition, authorized the army to intervene in order to protect governmental institutions. Armed incidents occurred between the military and the workers during which a number of protesters were killed. The tragic incident did not calm spirits but did the

\footnotetext{
65 Wenfang Tang, Public opinion and political change in China (Stanford, CA, 2005), p. 8.

66 Daniel Gros and Alfred Steinherr, Economic transition in Central and Eastern Europe: planting the seeds (Cambridge, 2004), p. 30 .
} 
contrary: in the following days, the riot extended to other cities and industrial centre in the Gdańsk region. ${ }^{67}$

Under the pressure of events, the Soviet leadership sent a secret letter to the Polish party, urging for a political, non-military solution to the crisis. As the Kremlin withdrew its support for Gomułka, the Polish Politburo decided to replace him with a younger leader, Edward Gierek. The new party first secretary engaged in dialogue with the protesters and made significant concessions on the prices issue, gradually succeeding in defusing the situation. ${ }^{68}$ Protests continued sporadically until mid-February the next year. Gierek used welfare measure to mitigate discontents, strongly supported by Moscow who provided credits. ${ }^{69}$ Poland was of a paramount importance in Soviet strategic planning due to its geographical position and the Soviets could not afford to lose the reliability of the Polish army, in the same way that they lost it in Czechoslovakia after the intervention. $7^{\circ}$

In early January 1971, Edward Gierek sent emissaries to all communist countries in Europe, to inform of the events that had occurred in Poland and provide the much-awaited reassurances of stability. Ceaussescu was visited on 7 January 1971 by Politburo member Stefan Olszowski. He presented Ceaussescu with the party's version of the events: the leadership, he said, had been isolated from the working masses and failed to provide solutions for the problems; combined with hostile propaganda and the authoritarian position of the first secretary, this all led to the outbreak of riots and social unrest. The Communist Party, Olszowski claimed, was at that time in full control of the situation and was working hard to set things straight. ${ }^{71}$

The first thing that Ceausescu asked was how the intellectuals behaved in the context of the crisis. Olszowski answered that the party did not have significant problems with the intellectuals who had been - for most of the time - silent with regard to the events. Ceaussescu confessed that he had been very concerned to observe the events in Poland but was pleased to hear that the party was in control:

I do not wish to hide one thing - Ceausescu said - that the events which took place preoccupied us and caused us great bitterness. Also, we saluted the fact that the party

\footnotetext{
67 A. Kemp-Welch, Poland under communism: a Cold War history (Cambridge, 20o8), pp. $182-6$. 68 Ibid., pp. 193-7.

69 Andrzej Paczkowski, The Spring will be ours: Poland and the Poles from occupation to freedom, trans. Jane Cave (University Park, PA, 2003), pp. 351-2.

$7^{\circ}$ Andrew A. Michta, Red eagle: the army in Polish politics, I944-I99o (Stanford, CA, 1990), p. 70 .

${ }^{11}$ Stenograma convorbirilor tovarăşului Nicolae Ceauşescu, secretar general al Partidului Comunist Român, cu tovarăşul Stefan Olszowski, membru al Biroului Politic, secretar al CC al PMUP (Transcript of the talks held between cmd. N. Ceauşescu, secretary general of the Romanian Communist Party, and cmd. S. Olszowski, member of the Political Bureau, secretary of the Central Committee of PUWP), ANR, fund CC al PCR - section External Relations, file no. $1 / 1971$, pp. 4-9.
} 
managed to restore order and tranquility in quite a short time, so it could proceed to working out its issues. $7^{2}$

Ceaussescu insisted that the PCR was positively impressed that the Polish United Workers Party had started from admitting its own mistakes, instead of blaming foreign circles for what happened. This statement was not circumstantial: when intervening in Czechoslovakia, the Soviets and their partners claimed that socialism was under threat especially due to hostile propaganda and activities conducted from abroad. In the above-mentioned meetings with the Soviets, Romania's close relations with the West were also accused by Moscow. In order to discard an eventual pretext for intervention, it was important for Ceaussescu to demonstrate that the unrest was caused by the communist parties' own mistakes, not by imperialist circles abroad conducting hostile manoeuvres.

In April 1971, in Moscow, Ceauşescu met Gierek for the first time since the latter had become party leader. Gierek described the situation in Poland in positive terms and informed Ceaussescu that measures were being implemented to strengthen party organizations and the relation between the party and the working masses. Discussions focused primarily on economic issues. Gierek told Ceaussescu about his plans to organize the party congress by the end of the year and adopt a new Five-Year Plan providing for a significant increase in the field of consumer products. 73 Political considerations were kept aside.

Events in Poland can help explain the timing of the 'July theses'. Although visibly interested in strengthening party control over society even from the autumn of 1968, Ceaussescu seemed reluctant to engage in radical measures for over two years. It was in the spring of 1971, prior to his departure to Asia, that discussions gained another meaning, directed towards action. In February 1971, a Central Committee Plenum adopted measures aimed at increasing the role of workers and workers' assemblies in industrial management. His solution to the risk of social disturbances was not to increase production of consumer goods like Gierek did, nor to indulge in 'socialist consumerism', but rather to mobilize the masses in a Chinese spirit, for political and ideological unity around the leader. The difference in action could be explained by Soviet pressures, apart from Ceaussescu's personal disposition for radical action.

Further investigation of archival documents reveals that Ceaussescu did indeed perceive social pressures of a consumerist nature just like in any other communist country in Europe. It was only his reaction that was different. In a private conversation with Álvaro Cunhal, secretary general of PCP

72 Ibid., p. 23 .

73 Stenograma discuţiilor avute cu delegaţia Partidului Muncitoresc Unit Polonez, Moscova, 8 aprilie 1971 (Transcript of the talks held with the PUWP delegation, Moscow, 8 April 1971), ANR, fund CC al PCR - section External Relations, file no. 16/1971, pp. 29-31. 
(Portuguese Communist Party), Ceauşescu, when explaining the meaning of the 'July theses', confessed:

We achieved a unitary, socialist economy, but in peoples' consciousness foreign mentalities remain and it is necessary to pay greater attention to educating people, so they would understand relations in a socialist society. Certainly, there can be tendencies towards an easy living, towards working less, especially because we have positive results in the economic activity, and such manifestation could appear if we fail to conduct a good ideological activity. 74

Ceaussescu told Cunhal that his party was employing great efforts to keep a close relation with the working masses, involving the workers in decisionmaking and consulting them at all times. Only by relying on the masses, he said, could a party avoid a situation similar to that in Poland.75 The fact that Ceaussescu had the events in Poland on his mind can also be circumstantially proved by another decision, made less than four months after the Polish riots: to increase salaries. In April 1971, the Executive Committee of the PCR decided to raise both salaries and the state allocations for children. ${ }^{6}$ Such sorts of measures were not characteristic of Ceausescu's social policies which relied mostly on persuasion or coercion, rather than stimulation.

Apart from the social turbulences in Poland, there is yet another aspect that needs to be considered in what concerns the timing of the 'Cultural minirevolution'. Changes of leadership occurred in some socialist countries starting in spring 1969, when Gustáv Husák replaced Dubček in Czechoslovakia. The events in Poland led to Gomułka's oust from power, as well, and, in May 1971, Ulbricht was also replaced in East Germany by Erich Honecker. Each change in particular had its own specific context and causalities but they did raise Ceaussescu's awareness of the risk. At this time, there is no proof that the Soviets were preparing a successor for Ceaussescu, as they did for Ulbricht, but the 'Cultural mini-revolution' was indeed accompanied by a wave of removals of high-ranking party cadres from key positions.

It is just as interesting that Ceausescu did establish an explicit connection between the leadership changes in the socialist countries and Moscow, stating that, in his opinion, it was the vulnerability of these leaders which allowed the Soviets to treat them as 'vassals' and ultimately sealed their fate, as Ceauşescu

74 Stenograma convorbirii purtate de tovarăşul Nicolae Ceauşescu, secretar general al Partidului Comunist Român, cu ocazia primirii tovarăşului Alvaro Cunhal, secretar general al Partidului Comunist Portughez (Transcript of the conversation held between cmd. N. Ceaussescu, secretary general of the Romanian Communist party, and cmd. A. Cunhal, secretary general of the Portuguese Communist party), ANR, fund CC al PCR - section External Relations, file no. 61/1971, p. $16 . \quad 75$ Ibid., p. 24.

${ }^{6}$ Protocol nr. 12 al Comitetului Executiv din ziua de 15 aprilie 1971 (Protocol no. 12 of the Executive Committee, 15 April 1971), ANR, fund CC al PCR - section Chancellery, file no. $42 / 1971$, p. 4 . 
confessed in a conversation with Santiago Carillo, leader of the Spanish Communist Party:

Ulbricht, the best friend of the Soviet Union, went to their Congress, they talked, they kissed each other, and when he returned home they removed him. Even the landlord treated his servant better-that's the reality. This is how such leaders are treated and, after all, they don't deserve to be treated otherwise, if they behave like that. 77

It is evident that in Ceauşescu's view, a weak relation between party and people involved two risks: on one hand, a risk of social disturbances, as seen in Czechoslovakia and Poland, and on the other hand, a risk to the leader's own power. The changes of 1969-71 probably convinced him that the measures taken up to that point in order to improve party-people relations had not been sufficient to insure him against any risk. This is why, only months after the removal of Gomułka and Ulbricht, Ceaussescu felt the need to take further measures in order to increase his stability in power. This is also how the time gap between the events of 1968 and the 'Cultural mini-revolution' of 1971 becomes explainable.

\section{V}

The 'July theses' marked an unexpected and radical turn in Romania's domestic politics during the communist regime. Although one of the least liberal countries in the communist bloc, Romania had experienced an ideologically relaxed regime after 1964, as Romanian-Soviet divergences emerged and the regime embarked on a national-communist course. In the field of culture, especially, Western authors and translations found increasingly more space in Romanian publications and ideological norms of 'socialist realism' appeared to be abandoned. For many years, the regime emphasized national rather than Marxist-Leninist values and, as contacts with the West intensified at all levels, it created the impression that Romania was headed "back to Europe".

When Ceausescu publicized his 'July theses', the first impression in Romanian society was that of shock. This study does not deny domestic preconditions such as Nicolae Ceauşescu's personal tendencies towards Stalinist approaches or the limited amount of freedoms and liberties that existed in Romania up to that point, but instead the analysis focused on the influence of foreign factors in determining both the content and the timing of the change.

77 Stenograma convorbirii tovarăşului Nicolae Ceauşescu, secretar general al Partidului Comunist Român, cu delegaţia Partidului Comunist din Spania, condusă de tovarăşul Santiago Carillo, secretar general al PC din Spania (Transcript of the conversation held by cmd. N. Ceaussescu, secretary general of the Romanian Communist party, with the delegation of the Communist Party of Spain, led by cmd. Santiago Carillo, secretary general), ANR, fund CC al PCR - section External Relations, file no. 63/1971, p. 76 . 
Ceausescu announced the change shortly after visiting China and North Korea which gave credit to the idea that he was inspired by what he had seen there. Archival insight demonstrates that basic principles of the 'Cultural minirevolution' had been discussed in the PCR leadership long before Ceaussescu's visit to Asia and had much deeper implications. The political core of the 'July theses' had been consolidating the party's political control and limiting foreign influences. From this point of view, it is now clear that the first steps in this direction had already been undertaken in the autumn of 1968 , following the Soviet-led invasion of Czechoslovakia.

In this case, connections between a foreign threat and the dynamic of domestic change cannot be disregarded. As he had been publicly antagonizing the Soviets for a long time, Ceaussescu certainly felt vulnerable in the aftermath of the intervention in Czechoslovakia. In order to resist successfully any pressures from abroad, Ceaussescu needed to rely on all segments of society. He chose not to meet social expectations by increasing welfare or living conditions, as the other Communist countries did, but rather asked society to meet the expectations of the party. His solution was not compromise, but persuasion.

There certainly are similarities with the situation in China, but it is unlikely that the regime in Romania was trying to replicate Chinese solutions. Rather, it seems more plausible that similar conditions - pressure from a foreign power, autochthonic visions of development, and perceptions of insufficient party control-led to similar solutions. When returning from China, Ceauşescu himself stated that what he had seen confirmed he was right in his party-centric analysis of social relations. From this point of view, it is reasonable to consider that the role of the Soviet factor was to determine change, while the Chinese factor only precipitated it.

Events in Poland, in December 1970, played a similar role, of precipitating the change. For Ceauşescu, it was a confirmation that the party had to keep in close touch with the 'working class', but he did not envisage that in a reciprocal manner, but mostly unilateral. To him, dialogue meant that the party had to convince the workers it was right and to mobilize them for the achievement of its ideological goals. Dealing with society by means of persuasion and mobilization was his Chinese-style solution to obtain unity around the party and the leader, necessary to withstand foreign pressures. 